\title{
Bottom ash obtained from biomass burning in fluidised-bed boilers as a mortar component
}

\author{
Waldemar Kępys ${ }^{1, *}$ \\ ${ }^{1}$ AGH University of Science and Technology, Faculty of Mining and Geoengineering, \\ Mickiewicza 30 Av. 30-065 Crakow, Poland
}

\begin{abstract}
The production of energy from biomass causes generation of solid waste, in the forms of fly ash and bottom ash. Owing to both economic considerations and environmental protection, it is required to recover those types of waste. The physical and economic properties of bottom ash indicate that waste ash can constitute a substitute of sand in the production of mortars. Consequently, tests were performed on the influence of bottom ash, used as sand substitute, on the mechanical properties of mortar. The test results indicated a possibility of using bottom ash as a mortar component
\end{abstract}

\section{Introduction}

Electrical and heat energy generation in Poland is based on fossil fuel burning, similarly to many other countries. The intention to reduce $\mathrm{CO}_{2}$ emission caused the necessity to replace coal by biomass in the co-burning process, or otherwise coal was completely withdrawn for the sake of biomass to be burned in power boilers. Similarly to the case of coal, biomass burning causes the generation of side products. Those products contain bottom ash, constituting part of the batch fed to the fluidised-bed boiler and/or noncombustible substances collected from the boiler, as well as flue gases consisting of fine particles collected from exhaust gas by dust removing equipment, together with the gas purification products. Regardless of the type of waste, it should be, first of all, recovered, in accordance with the hierarchy of waste control operations.

The process of ash generation during coal or biomass burning has been presented in detail in literature [1,2]. The ash properties depend on a number of factors, including the following: type of fuel, method of fuel preparation, type of the boiler, burning process parameters, method of ash recovery and storage, as well as the method of exhaust-gas purification to remove solid and gas pollution [3].

One can distinguish several groups of biomasses that are most often used in power generation: wood and woody biomasses, herbaceous and agricultural biomasses, aquatic biomasses, or animal biomasses $[4,5]$. The very type of biomass, its origin, and the method of plant growing influence the physical and chemical properties of combustion products. Consequently, those properties are crucial for subsequent waste handling. Nevertheless, when comparing the properties of the ashes generated from coal and biomass burning in

*Corresponding author: kepys@agh.edu.pl 
power plants, we should conclude that the basic element content is the same in terms of quality. However, differences occur in the proportions of particular elements and chemical compounds $[6,7]$.

The applications of coal-burning products have been known around the world for a number of years. Such waste is primarily used in construction industry as partial cement replacement, mineral additive to cement production, adsorbent, light-weight aggregate, mine backfill, road sub-base, and there are many other industrial uses of ashes $[6,8]$. According to $[9,10]$, the application of bottom ashes generated from coal burning, as partial replacement of sand in concrete, influences the workability, setting times, bleeding rate, and plastic shrinkage of fresh concrete. In the case of hardened concrete, bottom ash affects its density, strength, porosity, and durability. The identified reduction of concrete resistance was mainly caused by higher porosity and higher water demand when bottom ash was used. Besides, [11] stated that the use of bottom ash as fine aggregate in concrete, in the proportion of up to $50 \%$ of the replacement level, did not negatively affect the concrete strength and durability.

The burning of biomass alone generated waste whose physical and chemical properties differed from those of waste generated by coal burning. Such findings require implementation of a series of tests to establish the usability of various types of waste in the applications under discussion. The published test results refer to the use of waste from biomass burning in the building industry and road construction, as fertiliser or land reclamation additive or in mining $[12,13]$. The limitations of the application of ashes generated from biomass burning result from the following: efficiency of biomass combustion, difficulty in delivering and preparing sufficient amounts of biomasses, cost, and technological requirements [14]. Consequently, ashes are often dumped and that is not beneficial for the environment, owing to the occupation of land and negative influence on soil, water, and air.

For that reason, research was implemented to identify the uses of bottom ash obtained from biomass burning in the building industry, as substitute of sand in the production of mortars.

\section{Materials and experimental methods}

In tests, used biomass bottom ash (BBA), generated as a result of biomass burning in a fluidised-bed boiler (CFB). Biomass had the form of wood chips and pellets made of sunflower shells. Those materials were mixed before delivery to the boiler. The proportion of wood chips was 70-80\% wt. and the pellets constituted the rest. Waste was subjected to physical, chemical, and mineralogical testing. The grain content was determined by sieve analysis in accordance with the EN 933-1 Standard, while real density was determined by the pycnometric helium technique, using a Micrometrics Multivolume Pycnometer. The chemical composition was determined by using a mass spectrometer, with inductively coupled plasma mass spectrometry (ICP-MS) and inductively coupled plasma atomic emission spectroscopy (ICP-AES). Crystalline phases were detected by X-ray diffraction (XRD). To determine the influence of bottom ash on the soil and water environment, a leaching test was conducted, in accordance with the EN 12457-2 Standard. Distilled water was mixed with waste in the proportion of 1:10. The $\mathrm{pH}$ index was established for the aqueous extract and the content of pollution was identified as well, with the use of ICPAES and ICP-MS. Chloride was analyzed by using the Volhard titration method. The loss of ignition was determined in accordance with the EN 1744-1 Standard, in the temperature of $975^{\circ} \mathrm{C}$, during one hour.

Analysts conducted a series of tests of the usability of BBA as artificial aggregate by replacing sand with ash in the production of building materials. Usability was determined 
on the basis of the examination of mechanical properties of mortars. First, control mortar was produced, with plastic consistency, containing 1 part of cement mass and 3 parts of sand mass, with the water-cement proportion of 0.5. Next test mortars were produced. The sand portions were replaced with BBA, in the proportions of 25,50 , and $75 \%$ wt., respectively. Besides, mortar with a $100 \%$ BBA content was mixed. Portland cement CEM I 42.5R and standardised sand were applied. The water-to-cement proportion was the same in each mortar type and it amounted to 0.5. The mortar contents, with marking, are specified in Table 3. The mortars were mixed in accordance with the EN 196-1 Standard and placed in the box moulds, with the dimensions of 40x40x160 mm. The concrete bars were kept in moulds during 24 hours and, after recovery from moulds, in water until strength testing. The compression and flexural strength tests were conducted after 2, 7, and 28 days from sample production, in accordance with the EN 196-1 Standard.

\section{Results and discussion}

\subsection{The properties of bottom ashes generated from biomass burning}

Grain examinations were conducted owing to the influence of the aggregate grain structure on workability and on mechanical strength through compactness of the bodies [19]. The BBA grain content is presented in Fig. 1. The grains of the sizes below $2 \mathrm{~mm}$ constituted $95 \%$ of the quantity. According to the EN 13139 "Aggregate for Mortars" Standard, BBA belongs to fine aggregates $(0 / 2 \mathrm{~mm})$. The loss of ignition amounted to $0.3 \%$ for BBA, which indicated an insignificant content of unburned biomass in ash. That was much less in comparison to blast-furnace slag, being a popular artificial aggregate. As to slag, the allowed loss of ignition amounts to 3\% (under the EN 13139 Standard), while the EN 450-1 Standard allows for loss of ignition at 7\% in slag. The BBA grain density amounted to $2.58 \mathrm{~g} / \mathrm{cm}^{3}$ and that of sand to $2.63 \mathrm{~g} / \mathrm{cm}^{3}$.

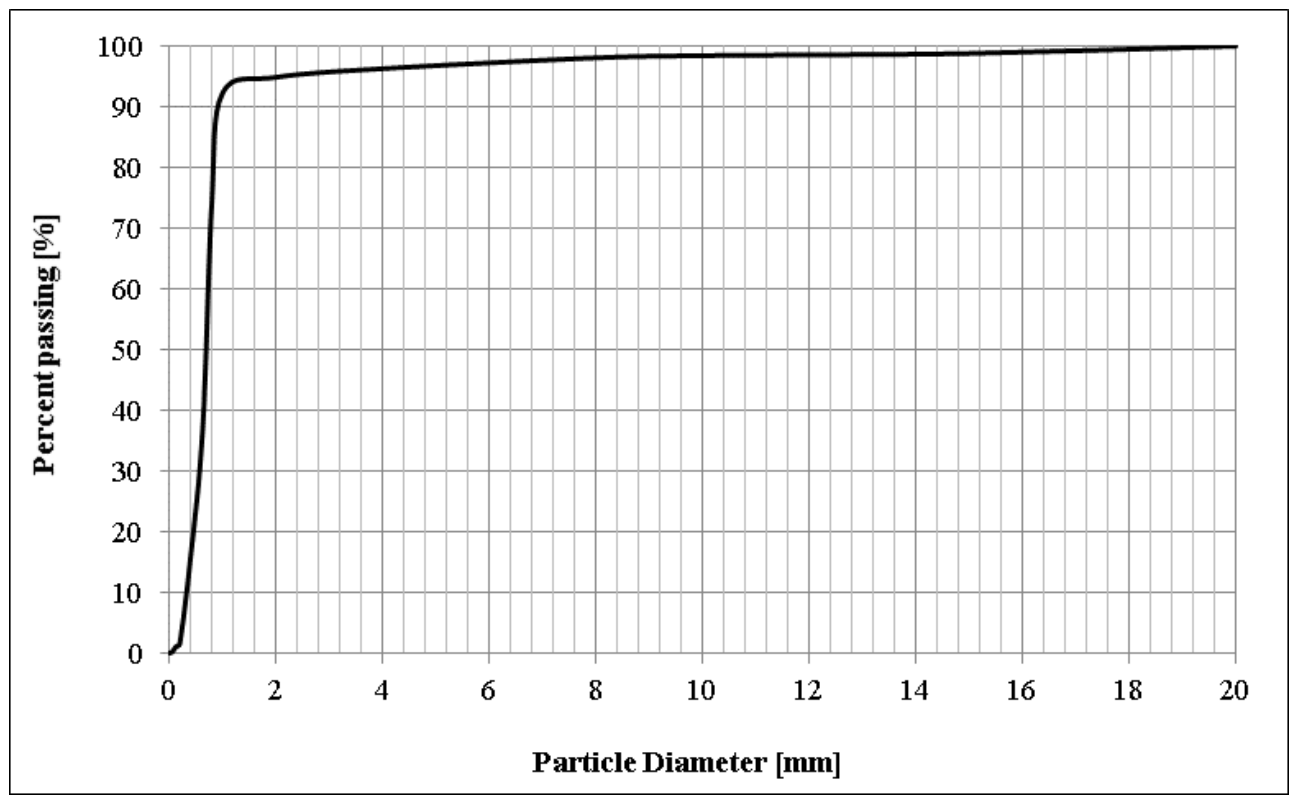

Fig. 1. Particle size distribution of BBA 
$\mathrm{SiO}_{2}$ was the main BBA component. Its share amounted to $84 \%$ wt. (tab. 1) The contents of the remaining components, e.g. those of $\mathrm{CaO}, \mathrm{Al}_{2} \mathrm{O}_{3}$, and $\mathrm{P}_{2} \mathrm{O}_{5}$, were at the level of several percent each. Only the $\mathrm{SO}_{3}$ content displayed $0.71 \%$ wt. (with the allowed $3 \%$ for ashes used in concrete mixing, according to the EN 450-1 Standard). That figure is essential because sulphates can cause an excessive increase of mortar swelling. The $\mathrm{SiO}_{2}$ content originates directly from the use of sand as the batch material in the boiler and its origin is associated with the transfer of sand and dirt to biomass during harvesting. That was further confirmed by phase content analysis (Fig. 2) where $\mathrm{SiO}_{2}$ quartz was a dominating component, accompanied by insignificant quantities of other forms of silica (crystobalite and keatite), generated during quartz sand baking. BBA also contained the residues of silt minerals: montmorillonite $\mathrm{Al}_{2} \mathrm{O}_{3} \cdot \mathrm{SiO}_{2} \cdot \mathrm{nH}_{2} \mathrm{O}$ and trace quantities of anhydrite $\mathrm{CaSO}_{4}$ and hematite $\mathrm{Fe}_{2} \mathrm{O}_{3}$.

Table 1. Results of simulation tests for selected construction variants

\begin{tabular}{|c|c|c|c|c|c|c|c|c|c|}
\hline \multicolumn{10}{|c|}{ Parameters (\%wt) } \\
\hline $\mathrm{SiO}_{2}$ & $\mathrm{CaO}$ & $\mathrm{Al}_{2} \mathrm{O}_{3}$ & $\mathrm{P}_{2} \mathrm{O}_{5}$ & $\mathrm{Fe}_{2} \mathrm{O}_{3}$ & $\mathrm{MgO}$ & $\mathrm{K}_{2} \mathrm{O}$ & $\mathrm{SO}_{3}$ & $\mathrm{Mn}_{2} \mathrm{O}_{5}$ & $\mathrm{Na}_{2} \mathrm{O}$ \\
\hline 84.11 & 5.47 & 3.85 & 2.00 & 1.21 & 1.52 & 0.71 & 0.71 & 0.18 & 0.09 \\
\hline
\end{tabular}

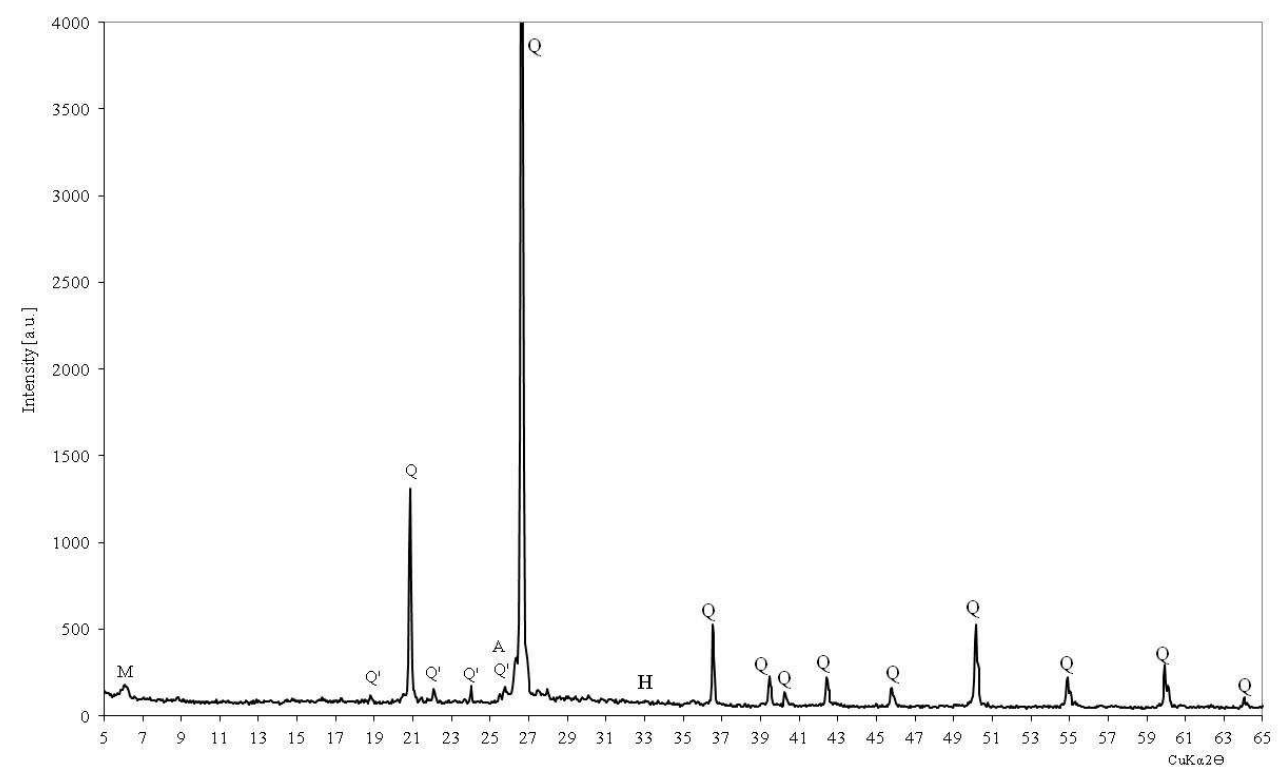

Fig. 2. X-ray diffraction of BBA (Q - quartz, Q' - other forms of silica, M - clay minerals, $\mathrm{H}$ - hematite, $\mathrm{A}$ - anhydrite)

The results of testing substance leaching from BBA are presented in Table 2. The data indicate a very small content of soluble components: chlorides, sulphates, or heavy metals found in BBA. When bottom ash is used to replace sand in mortar, pollution leaching is essential from the viewpoint of mortar's influence on the soil and water environment. Besides, the presence of chlorides negatively influences mortar durability, as well as binding time [15]. Consequently, the allowed water-soluble chloride content in aggregates used for the production of mortar may not exceed $0.15 \% \mathrm{wt}$. 
Table 2. Leachnig test

\begin{tabular}{|c|c|c|c|}
\hline \multicolumn{4}{|c|}{ Concentration in leachates $\left[\mathrm{mg} / \mathrm{dm}^{3}\right]$} \\
\hline $\mathrm{pH}$ & 9.64 & $\mathrm{Ni}^{+2}$ & 0.00052 \\
\hline $\mathrm{Na}^{+}$ & 1.38 & $\mathrm{Co}^{+2}$ & 0.00006 \\
\hline $\mathrm{K}^{+}$ & 60.45 & $\mathrm{~Pb}^{+2}$ & 0.0003 \\
\hline $\mathrm{Ca}^{+2}$ & 30.34 & $\mathrm{Hg}^{+2}$ & 0.0014 \\
\hline $\mathrm{Mg}^{+2}$ & 1.6 & $\mathrm{Cd}^{2+}$ & 0.00026 \\
\hline $\mathrm{Ba}^{+2}$ & 0.01 & $\mathrm{Cr}^{3+}$ & 0.021 \\
\hline $\mathrm{Sr}^{+2}$ & 0.14 & $\mathrm{As}^{3+}$ & 0.0047 \\
\hline $\mathrm{Zn}^{+2}$ & $<0.002$ & $\mathrm{Cl}^{-}$ & 2.5 \\
\hline $\mathrm{Cu}^{+2}$ & 0.003 & $\mathrm{SO}_{4}^{-2}$ & 89.00 \\
\hline
\end{tabular}

\subsection{Mortar properties}

Table 3 presents the results of mortar compression tests, depending on mortar composition. Generally, sand replacement by BBA causes a reduction of strength, in comparison to that of control mortar (0BBA). That trend is maintained with the increase of the BBA content in mortar. After two days of seasoning, the strength of mortar containing BBA was from 27 to $22.5 \mathrm{MPa}$, with the value of control mortar strength of $29.1 \mathrm{MPa}$. The former results were by 7 to $22 \%$ lower from those of the control sample (Fig. 3). After 7 days, a considerable increase of strength occurred in all mortars, from 68 to $62 \%$, in comparison to the results obtained after 2 days. The control mortar strength amounted to 48.9 $\mathrm{MPa}$, while that of BBA mortars from 45.3 $\mathrm{MPa}$ (25BBA) to $36.4 \mathrm{MPa}$ (100BBA), which corresponded to the reduced strength from 7 to $25 \%$, in respect of the control mortar. The strength tests after 28 days indicated a further increase of compression strength in all mortars, although the increase of strength, in comparison to the results after 7 days, reached $17 \%$ (25BBA), $11 \%$ (50BBA), $10 \%$ (75BBA), and $8 \%$ (100BBA), with the $20 \%$ increase of strength in the control mortar. After 28 days, the mortar compression strength was reduced, depending on the BBA content: from $53 \mathrm{MPa}$ (25\% of BBA) to $41.8 \mathrm{MPa}$ (75\% of $\mathrm{BBA}$ ), while that of the mortar with BBA alone amounted to $39.4 \mathrm{MPa}$, with $58 \mathrm{MPa}$ for the control mortar.

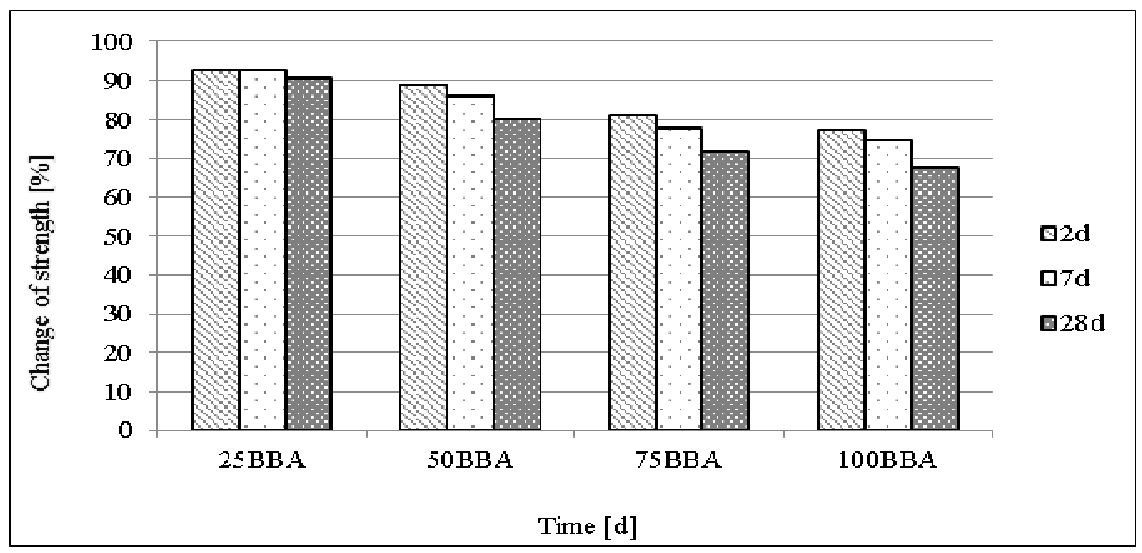

Fig. 3. Changes in the mortar compression strengths in comparison to that of the control mortar 
Table 3. Mortar content and the flexural and compression strengths

\begin{tabular}{|c|c|c|c|c|c|c|c|c|c|}
\hline \multirow{2}{*}{ Sample } & \multicolumn{4}{|c|}{ Components } & \multirow{2}{*}{$\begin{array}{c}\text { BBA/ } \\
\text { Sand } \\
{[\%]}\end{array}$} & \multirow{2}{*}{$\begin{array}{c}\begin{array}{c}\text { Flexural } \\
\text { strength } \\
{[\mathrm{MPa}]}\end{array} \\
28 \mathrm{~d}\end{array}$} & \multicolumn{3}{|c|}{$\begin{array}{c}\text { Compressive strength } \\
{[\mathrm{MPa}]}\end{array}$} \\
\hline & $\begin{array}{c}\text { Cement } \\
{[\mathrm{g}]}\end{array}$ & $\begin{array}{c}\text { Sand } \\
{[\mathrm{g}]}\end{array}$ & $\begin{array}{c}\mathrm{BBA} \\
{[\mathrm{g}]}\end{array}$ & $\begin{array}{l}\text { Water } \\
{\left[\mathrm{cm}^{3}\right]}\end{array}$ & & & $2 d$ & $7 d$ & $28 \mathrm{~d}$ \\
\hline 0BBA & 450 & 1350 & 0 & 225 & $0 / 100$ & 8.98 & 29.1 & 48.9 & 58.4 \\
\hline $25 \mathrm{BBA}$ & 450 & 1012.5 & 337.5 & 225 & $25 / 75$ & 8.57 & 27.0 & 45.3 & 53.0 \\
\hline $50 \mathrm{BBA}$ & 450 & 675 & 675 & 225 & $50 / 50$ & 8.25 & 25.8 & 42.0 & 46.8 \\
\hline $75 \mathrm{BBA}$ & 450 & 337.5 & 1012.5 & 225 & $75 / 25$ & 7.36 & 23.6 & 38.0 & 41.8 \\
\hline $100 \mathrm{BBA}$ & 450 & 0 & 1350 & 225 & $100 / 0$ & 6.79 & 22.5 & 36.4 & 39.4 \\
\hline
\end{tabular}

\section{Conclusion}

Mineral waste is generally applied as artificial aggregate in the production of various types of aggregate mixes for road construction or mortar and concrete mixing. That allows for reducing the consumption of natural aggregates, with the additional disposal of waste. Both effects are beneficial for the natural environment.

This paper presents research intended to determine the possibilities of using bottom ash originating from biomass burning in a fluidised-bed boiler in mortar production. The grain content tests indicated that ash was classified as fine aggregate, with a $95 \%$ content of grain of up to $2 \mathrm{~mm}$ in size. $\mathrm{SiO}_{2}$ was the main ahs component, with the $84 \%$ wt. content and insignificant shares of sulphates and chlorides. Bottom ash from biomass constituted a substitute of sand in cement mortar, with the ash content from $25 \%$ to $100 \%$. The mortar compression tests indicated that the compression strength was reducing with the increase of the bottom ash proportion in mortar, in comparison to the control mortar (free of ash). Nevertheless, it is possible to use bottom ash as sand replacement in mortars, with a proper selection of mortar-mix proportions, depending on future application.

This study was conducted under statutory research of the Department of Environmental Engineering and Mineral Raw Material Processing (Project No. 11.11.100.482), Faculty of Mining and Geoengineering, AGH University of Science and Technology in Kraków, Poland.

\section{References}

1. Vassilev S.V., Baxter D., Andersen L. K., Vassileva Ch. G.: An overview of the behaviour of biomass during combustion: Part I. Phase-mineral transformations of organic and inorganic matter, Fuel, 112, pp. 391-449, (2013)

2. Vassilev S.V., Baxter D., Andersen L. K., Vassileva Ch. G.: An overview of the behaviour of biomass during combustion: Part II. Ash fusion and ash formation mechanisms of biomass types, Fuel, 117, pp.152-183, (2014)

3. Grammelis P., Skodras G., Kakaras E.: Effects of biomass co-firing with coal on ash properties. Part I: Characterisation and PSD, Fuel, 85, pp. 2310-2315, (2006)

4. Vassilev S.V., Baxter D., Andersen L. K., Vassileva Ch. G.: An overview of the chemical composition of biomass, Fuel, 89, 5, pp. 913-933, (2010)

5. Tortosa Masiá A.A., Buhre B.J.P., Gupta R.P., Wall T.F.: Characterising ash of biomass and waste, Fuel Processing Technology, 88, pp. 1071-1081, (2007)

6. Ahmaruzzaman M.: A review on the utilization of fly ash. Progress in Energy and Combustion Science, 36, pp. 327-363, (2010) 
7. Williams A., Jones J.M., Ma L., Pourkashanian M.: Pollutants from the combustion of solid biomass fuels, Progress in Energy and Combustion Science, 38, pp. 113-137, (2012)

8. Kurama H., Kaya M.: Usage of coal combustion bottom ash in concrete mixture, Construction and Building Materials, 22, pp. 1922-1928, (2008)

9. Singh M., Siddique R.: Effect of coal bottom ash as partial replacement of sand on properties of concrete. Resources, Conservation and Recycling, 72, pp. 20-32, (2013)

10. Andrade L.B., Rocha J.C., Cheriaf M.: Influence of coal bottom ash as fine aggregate on fresh properties of concrete, Construction and Building Materials, 23, pp. 609-614, (2009)

11. Singh M., Siddique R.: Properties of concrete containing high volumes of coal bottom ash as fine aggregate. Journal of Cleaner Production, 91, pp. 269-278, (2015)

12. Wang S., Miller A., Llamazos E., Fonseca F., Baxter L.: Biomass fly ash in concrete: Mixture proportioning and mechanical properties. Fuel, 87, pp. 365-371, (2008)

13. Kępys W., Pomykała R.: Research into the Usefulness of Ash from the Co-Combustion of Lignite and Biomass in Mining Technologies. Polish Journal of Environmental Studies, 23, pp. 1381-1384, (2014)

14. Cabrera M., Galvin A.P., Agrela F., Carvajal M.D., Ayuso J.: Characterisation and technical feasibility of using biomass bottom ash for civil infrastructures. Construction and Building Materials, 58, pp. 234-244, (2014)

15. Modolo R.C.E., Ferreira V.M., Tarelho L.A., Labrincha J.A., Senff L., Silva L. Mortar formulations with bottom ash from biomass combustion. Construction and Building Materials, 45, pp. 275-281, (2013) 